\title{
BUDAYA ORGANISASI DALAM PENDIDIKAN ISLAM
}

\author{
Abdul Basyit \\ abdulbasyit@umt.ac.id \\ (Fakultas Agama Islam, Universitas Muhammadiyah Tangerang)
}

\begin{abstract}
Abstrak:
Budaya organisasi sebagai perekat sosial, dan berguna pula sebagai mekanisme kontrol yang membentuk perilaku anggota. Budaya organisasi merupakan nilai, kepercayaan bersama para anggota organisasi. Budaya organisasi akan memberikan dampak positif pada kinerja institusi secara umum, budaya organisasi akan mengarahkan perilaku para anggota organisasi. Dalam lembaga pendidikan Islam, budaya organisasi dalam pendidikan islam terus bertujuan untuk mengejawantahkan ajaran dan nilai-nilai Islam yang pada akhirnya akan menjadi budaya Islami.
\end{abstract}

\section{Kata Kunci: Budaya Organisasi, Pendidikan Islam.}

\section{A. Pendahuluan}

Setiap individu memiliki kepribadian, begitu pula dengan organisasi. Individu yang memiliki kepribadian yang menjadi karakteristik yang berbeda antara individu satu dengan lainnya, demikian halnya dengan karakteristik organisasi yang menjadi pembeda dengan organisasi lainnya. Organisasi dapat digolongkan sesuai dengan sifat yang dimilikinya, selanjutnya dapat digunakan untuk memperkirakan sikap dan prilaku individu yang ada dalam organisasi.

Terdapat suatu variabel dalam organisasi yang memiliki peran yang sangat menentukan dalam pencapaian tujuan organisasi, walaupun sukar untuk ditentukan atau diuraikan secara seksama tatapi variabel itu ada, dan variabel tersebut biasanya diuraikan oleh prilaku orang-orang yang ada dalam organisasi dalam bentuk-bentuk yang umum. Variabel tersebut dengan istilah budaya dan iklim organisasi. Iklim organisasi juga menjadi sesuatu yang menarik untuk dikaji, dikarenakan kedua variabel dalam organisasi ini dapat dikatakan menjadi penentu bagi keefektifan organisasi dalam mencapai tujuannya. Jika diibaratkan sebuah senter, maka iklim organisasi adalah lampunya sedangkan budaya organisasi adalah baterainya. Sangat jelas sekali senter itu tidak akan bisa menyala jika baterainya tidak ada. Demikian pula dengan organisasi, Iklim yang ada dalam organisasi sangat ditentukan oleh bagaimana budaya yang berkembang dalam organisasi tersebut.

Dalam lembaga pendidikan Islam, budaya organisasi terus dibangun dan dibina dengan tujuan untuk mengejawantahkan ajaran dan nilai-nilai Islam yang pada akhirnya akan menjadi budaya Islami.

\section{B. Budaya Organisasi}

Kata kebudayaan berasal dari kata sansekerta buddhayah, yaitu bentuk jamak dari buddhi yang artinya akal. Dengan demikian kebudayaan dapat diartika sebagai: "hal-hal yang bersangkut-paut dengan akal." Dalam istilah "antropologibudaya" pengertian "budaya" sama dengan "kebudayaan". E.B. Taylor, Bapak dan pakar dunia Antropologi Budaya dalam Haryo S Martodirjdo, mendefinisikan budaya sebagai keseluruhan kompleks yang meliputi pengetahuan, kepercayaan, 
kesenian, moral, hukum, adat istiadat, dan kemampuan-kemampuan atau kebiasaankebiasaan lain yang diperoleh anggotaanggota suatu masyarakat. ${ }^{1}$

Mudji Sutrisno dalam bukunya (Teori-Teori Kebudayaan) mengartikan budaya sebagai kebiasaan-mungkin yang sudah mengakar lama hingga dianggap berasal dari suku atau struktur genetika seseorang. ${ }^{2}$ Menurut Joko Tri prasetya dalam bukunya (Ilmu Budaya Dasar) mendefinisikan budaya sebagai sebuah daya dari budi yang berupa cipta, karsa dan rasa. $^{3}$

Budaya adalah suatu pola asumsi dasar yang diciptakan, ditemukan, atau dikembangkan oleh kelompok tertentu sebagai pembelajaran untuk mengatasi masalah adaptasi eksternal dan integrasi internal yang resmi dan terlaksana dengan baik". Budaya diajarkan kepada anggotaanggota baru sebagai cara yang tepat memahami, memikirkan, dan merasakan terkait masalah-masalah tersebut.

Dengan demikian, bentuk atau wujud dari pengertian budaya dapat dilihat dalam tiga hal, yaitu:

1. budaya itu abstrak, budaya itu merupakan kepercayaan, asumsi dasar, gagasan, moral, norma, adat-istiadat, hukum atau peraturan.

2. budaya itu berupa sikap yang merupakan pola perilaku atau kebiasaan dari kegiatan manusia dalam lingkungan masyarakat, yang menggambarkan kemampuan beradaptasi, baik secara internal maupun eksternal.

3. budaya itu tampak secara fisik yang merupakan bentuk fisik hasil karya manusia.

\footnotetext{
${ }^{1}$ Haryo S Martodirjdo, Pemahaman Lintas Budaya, (Jakarta: PT. Raja Grafindo, 2004), h. 20

${ }^{2}$ Mudji Sutrisno, Teori-Teori Kebudayaan, (Jakarta: YKPN, 2003), h. 257

${ }^{3}$ Joko Tri prasetya, et. all., Ilmu Budaya Dasar, (Jakarta: MKDU, 2004), h. 28
}

Jadi budaya dapat didefinisikan sebagai keseluruhan pengetahuan manusia sebagai makluk sosial yang digunakannya untuk memahami dan menginterpretasikan lingkungan dan pengalamannya serta menjadi landasan bagi tingkah lakunya. Suatu kebudayaan merupakan milik bersama anggota suatu masyarakat atau suatu golongan sosial, yang penyebarannya kepada anggota-anggotanya dan pewarisan kepada generasi berikutnya dilakukan melalui proses belajar dan dengan menggunakan simbol-simbol yang terwujud dalam bentuk yang terucapkan maupun yang tidak.

Sebagai milik bersama anggota masyarakat atau suatu kelompok sosial, budaya menurut Ndaraha ${ }^{4}$ memiliki fungsi sebagai berikut:

1. Identitas dan citra suatu masyarakat

2. Pengikat suatu masyarakat

3. Sumber inspirasi

4. Kemampuan untuk membentuk nilai tambah

5. Pola prilaku

6. Budaya sebagai warisan

7. Pengganti formalisasi

8. Mekanisme adaptasi terhadap perubahan

9. Proses menjadikan bangsa kongruen dengan negara sehingga terbentuk nation state.

Sedangkan Organisasi merupakan bagian yang tidak terpisahkan dari kehidupan manusia. Setiap manusia hidup dalam sebuah organisasi. Organisasi didefinisikan beragam oleh para ahli. Variasi definisi ini didasarkan pada sudut pandang dan waktu ahli ketika mendefinisikan.

Robbins (Dalam tim dosen AP UPI) mendefiniskan organisasi sebagai "kesatuan sosial yang dikoordinasikans secara sadar, dengan sebuah batasan yang

${ }^{4}$ Ndraha, Taliziduhu, Budaya Organisasi, Jakarta: Rineka Cipta, 2003, h. 45 
relative dapat diidentifikasi, yang bekerja atas dasar yang relative terus menerus untuk mencapai suatu tujuan bersama atau sekelompok tujuan". Definisi dari Robbins ini menekankan pada organisasi sebagai sebuah sistem sosial yang perlu dikoordinasi dalam arti perlu manajemen. Batasan organisasi akan berubah sebagaimana tuntutan lingkungan organisasi, sehingga dikatakan relative. Definisi lain mengenai organisasi dikemukakan oleh Oteng Sutisna sebagaimana dikutip Tim Dosen AP UPI menyebutkan bahwa organisasi yakni "mekanisme yang mempersatukan kegiatan-kegiatan untuk menyelesaikan pekerjaan-pekerjaan". Definisi ini menekankan pada mekanisme pekerjaan dalam mencapai tujuan organisasi.

Dari pendapat-pendapat para ahli tersebut diatas, dapat disimpulkan bahwa organiasi merupakan suatu sistem interaksi diantara orang-orang untuk mencapai tujuan organisasi, dimana sistem tersebut memberikan arahan prilaku bagi anggotaanggotanya. ${ }^{5}$

Sedangkan Budaya organisasi adalah sebuah sistem makna bersama yang dianut oleh para anggota yang membedakan suatu organisasi dari organisasi-organisasi lainnya. ${ }^{6}$ Sistem makna bersama ini adalah sekumpulan karakteristik kunci yang dijunjung tinggi oleh organisasi. ${ }^{7}$

Pemahaman tentang budaya organisasi tentu tidak lepas dari konsep dasar tentang budaya, yang merupakan salah satu terminology dalam sosiologi. Menurut Edward yang dikutip oleh Akdon, mendefinisikan kebudayaan sebagai

\footnotetext{
${ }^{5}$ Tim Dosen, AP. UPI (2009). Manajemen Pendidikan. Bandung. Alfabeta, h. 47

${ }^{6}$ Schein, E. H. Organizational Culture and Leadership, San Fransisco: Jossey-Bass, 1985. h. 168

${ }^{7}$ Robbins, Stephen P.; Judge, Timothy A. (2008). Perilaku Organisasi Buku 2, Jakarta: Salemba Empat. h. 256-266
}

keseluruhan yang kompleks, yang di dalamnya terkandung pengetahuan, kepercayaan, kesenian, moral, hukum, adat istiadat, dan kemampuan-kemampuan lain yang didapat seseorang sebagai anggota masyarakat. ${ }^{8}$ Terdapat kesepakatan luas bahwa budaya organisasi merujuk pada sistem pengertian bersama yang dipegang oleh anggota-anggota suatu organisasi yang membedakan organisasi tersebut dengan organisasi lainnya). ${ }^{9} \quad$ Sistem pengertian bersama ini dalam pengamatan yang lebih seksama merupakan serangkaian karakter penting yang menjadi nilai bagi suatu organisasi.

Dari semua definisi tentang budaya organisasi diatas, secara umum dapat ditetapkan bahwa budaya organisasi berkaitan dengan makna bersama, nilai, sikap dan keyakinan. Dapat dikatakan bahwa jantung dari suatu organisasi adalah sikap, keyakinan, kebiasaan dan harapan dari seluruh individu anggota organisasi mulai dari manajemen puncak hingga manajemen yang paling rendah, sehingga tidak ada aktifitas manajemen yang dapat melepaskan diri dari budaya.

\section{Komponen-Komponen Organisasi}

Robbins dalam

Budaya

Soetopo $^{10}$

mengemukakan tujuh karakteristik budaya organisasi yaitu:

1. Otonomi individu yaitu kadar kebebasan, tanggung jawab dan kesempatan individu untuk berinisiatif dalam organisasi

\footnotetext{
${ }^{8}$ Hikmat, "Manajemaen Pendidikan", (Bandung: Pustaka Setia, 2011), h. 203

${ }^{9}$ Robbins, P.Stephen (2005).Organizational Behavior; Elevent Edition. Pearson Education.Inc., Upper Saddle, River. New Jersey. h. 485

${ }^{10}$ Soetopo, Hendyat (2010). Perilaku Organisasi; Teori dan Praktek di Bidang Pendidikan. Bandung. Remaja Rosdakarya. h. 49
} 
2. Struktur yaitu kadar peraturan dan ketetapan yang digunakan untuk mengontrol prilaku pegawai

3. Dukungan yaitu kadar bantuan dan keramahan manajer kepada pegawai

4. Identitas yaitu kadar kenalnya anggota terhadap organisasinya secara keseluruhan, terutama informasi kelompok kerja dan keahlian profesionalnya

5. Hadiah performansi yaitu kadar alokasi hadiah yang didasarkan pada criteria performansi pegawai

6. Toleransi konflik yaitu kadar konflik dalam hubungan antar sejawat dan kemauan untuk jujur dan terbuka terhadap perbedaan

7. Toleransi resiko yaitu kadar dorongan terhadap pegawai untuk agresif, inovatif dan berani menanggung resiko.

\section{Fungsi Budaya Organisasi}

Soetopo $^{11}$ mengemukan bahwa fungsi budaya organisasi bergayut dengan fungsi eksternal dan fungsi internal. Fungsi eksternal budaya organisasi adalah melakukan adaptasi terhadap lingkungan diluar organisasi, sementara fungsi internal berkaitan dengan integrasi berbagai sumber daya yang ada didalamnya termasuk sumber daya manusia. Jadi secara eksternal budaya organisasi akan selalu beradaptasi dengan budaya-budaya yang ada diluar organisasi, begitu seterusnya sehingga budaya organisasi tetap akan selalu ada penyesuaianpenyesuaian. Lebih lanjut Soetopo menjelaskan bahwa makin kuat budaya organisasi, makin tidak mudah organisasi itu akan terpengaruh oleh budaya luar yang berkembang di lingkungannya. Sementara kekentalan fungsi internal makin dirasakan menguat jika didalam organisasi itu

\footnotetext{
${ }^{11}$ Soetopo, Hendyat (2010). Perilaku Organisasi; Teori dan Praktek di Bidang Pendidikan. Bandung: Remaja Rosdakarya, h.52
}

semakin berkembang norma-norma, peraturan, treadisi, adat istiadat organisasi yang terus menerus dipupuk oleh para anggotanya sehingga berangsur-angsur budaya itu akan menajdi semakin kuat.

Wayne K. Hoy dan Cecil G.Miskel ${ }^{12}$ mengemukakan tentang fungsi budaya dalam organisasi menjadi lima fungsi yaitu:

1. Budaya memiliki suatu peran batasbatas tertentu yaitu budaya menciptakan perbedaan antara satu organisasi dengan organisasi lainnya.

2. Budaya menyampaikan rasa identitas kepada anggota-anggota organisasi

3. Budaya mempermudah penerusan komitmen hingga mencapai batasan yang lebih luas, melebihi batasan ketertarikan individu

4. Budaya mendorong stabilitas sistem sosial. Budaya merupakan suatu ikatan sosial yang membantu mengikat kebersamaan organisasi dengan menyediakan standar-standar yang sesuai mengenai apa yang harus dikatakan dan dilakukan karyawan

5. Budaya sebagai pembentuk rasa dan mekanisme pengendalian yang memberikan panduan dan bentuk prilaku serta sikap karyawan.

Dalam organisasi, seringkali terjadi pembandingan antara budaya yang kuat dan budaya yang lemah. Alasan ini seringkali memiliki dampak yang lebih besar terhadap sikap karyawan dan lebih tertuju langsung untuk mengurangi keluar masuknya karywan. Dalam hal ini, Robbins menjelaskan bahwa budaya yang kuat selalu ditandai oleh nilai-nilai inti organisasi yang dipegang kukuh dan disepkati secara luas. Semakin banyak

\footnotetext{
${ }^{12}$ Wayne K.Hoy dan Cecil G.Miskel, Administrasi dan Pendidikan (Teori, Riset, dan Praktik) diterjemahkan dari "Educational Administrational" Pustaka Pelajar Yogyakarta, 2013, h. 277-278
} 
anggota organisasi yang menerima nilainilai inti dan semakin besar komitmen mereka terhadap nilai-nilai tersebut, maka budaya tersebut akan semakin kuat. Sejalan dengan definisi ini, suatu budaya yang kuat jelas sekali memiliki pengaruh yang besar dalam sikap anggota organisasi dibandingkan dengan budaya yang lemah.

Hasil spesifik dari suatu budaya yang kuat adalah keluar masuknya pekerja yang rendah. Suatu budaya yang kuat akan memperlihatkan kesepakatan yang tinggi mengenai tujuan organisasi diantara anggota-anggotanya. Kebulatan suara terhadap tujuan akan membentuk keterikatan, kesetiaan, dan komitmen organisasi. Kondisi ini selanjutnya akan mengurangi kecendrungan karyawan untuk keluar dari organisasi.

\section{E. Karakteristik Budaya Organisasi}

Ada tujuh karakteristik utama budaya organisasi, yakni:

1. Inovasi dan keberanian mengambil resiko, dalam hal ini terkait sejauhmana anggota didorong untuk bersikap inovatif dan berani mengambil resiko.

2. Perhatian pada hal hal rinci, yakni anggota diharapkan menjalankan presisi, analisis, dan perhatian pada hal-hal kecil.

3. Orientasi hasil adalah tentang sejauh manajemen berfokus pada hasil dibandingkan pada teknik dan proses yang digunakan untuk mencapai hasil tersebut

4. Orientasi orang, terkait sejauh mana keputusan keputusan manajemen mempertimbangkan efek dari hasil tersebut terhadap orang yang ada dalam organisasi.

5. Orientasi tim. Sejauh mana kegiatan kegiatan keraj organisasi pada tim ketimbang pada individu.
6. Keagresifan. Terkait sejauh mana orang bersifat agresif dan kompetitif ketimbang santai.

7. Stabilits. Sejauh mana kegiatankegiatan organisasi menekankan dipertahankannya status quo dalam perbandingannya dengan pertumbuhan. ${ }^{13}$

Masing-masing karakteristik diatas bergerak pada suatu kontinuitas dari rendah hingga ke tinggi. Menilai suatu organisasi dengan ketujuh karakter ini akan menghasilkan gambaran mengenai budaya organisasi tersebut. Gambaran tersebut kemudian menjadi dasar untuk perasaan saling memahami yang dimiliki anggota organisasi mengenai organisasi mereka, bagaimana segala sesuatu dikerjakan berdasarkan pengertian bersama tersebut, dan cara-cara anggota organisasi seharusnya bersikap. ${ }^{14}$

\section{F. Klasifikasi Budaya Organisasi}

Dalam mempelajari budaya organisasi, terdapat empat pendekatan menurut Robert dan Hunt dalam Soetopo ${ }^{15}$ Keempat pendekatan itu antara lain: (1) beberapa sarjana memandangnya sebagai asumsi bersama, keyakinan dan nilai-nilai dalam organisasi dan kelompok kerja, (2) kelompok kedua tertarik dengan mitos, cerita, dan bahasa sebagai manifestasi budaya, (3) memandang tata cara dan

\footnotetext{
${ }^{13}$ O'Reilly; Chatman, J; Caldwell, D. F. "People and Organizational Culture: A Profile Comparison Approach to Assessing PersonOrganization Fit," Academy of Management Journal, hlm. 487-516. Lihat juga Stephen P. Robbins dan Timothy A. Juge, "Perilaku Organisasi", h. 256-257.

${ }^{14}$ Robbins, P. Stephen (2005). Organizational Behavior; Elevent Edition. Pearson Education.Inc., Upper Saddle, River. New Jersey h. 486

${ }^{15}$ Soetopo, Hendyat (2010). Perilaku Organisasi; Teori dan Praktek di Bidang Pendidikan. Bandung. Remaja Rosdakarya, h. 42
} 
seremonial sebagai manifestasi budaya, dan (4) mempelajari interaksi antar anggota dan symbol-simbol. Sedangkan Schein membaginya kedalam tiga dimensi budaya yaitu: (1) artefak dan kreasi berupa teknologi, seni, pola prilaku yang dapat dilihat dan didengar. Terlihat oleh mata tetapi sering tidak dapat diartikan dan diuraikan, (2) nilai, dapat diuji dalam lingkungan fisik, dapat diuji hanya oleh konsensus social. Tingkat yang lebih tinggi mengenai kesadaran, (3) asumsi dasar, yaitu menegnai hubungan manusialingkungan, hakikat dasar manusia, hakikat hubungan manusia.

Sedangkan Hellriegel dan Slocum dalam Soetopo mengajukan kerangka klasifikasi budaya organisasi sebagai berikut: Sumbu vertical mencerminkan orientasi pengawasan yang relative normal, jarak dari mantap ke fleksibel. Sumbu horizontal mencerminkan fokus relative terhadap perhatian, jarak dari fungsi internal ke fungsi eksternal. Sudut-sudut dari empat persegi mewakili empat tipe murni dari budaya organisasi yaitu birokratik, clan, entrepreneurial dan pasar.

1. Budaya Birokratik. Suatu organisasi dengan karyawan yang mempunyai formalisasi nilai peraturan standar prosedur operasi dan koordinasi hierarkis. Perhatian jangka panjang dalam birokrasi, efisiensi, dan stabilitas dapat diperkirakan. Karyawannya mempunyai standar nilai yang tinggi terhadap pelayanan pelanggan. Manajer memandang peran mereka sebagai koordinator yang baik, organisator dan memperkuat standard dan aturan tertulis.

2. Budaya Clan, mempunyai atribusi tradisi, kesetiaan, komitmen pribadi, sosialisasi ekstensif, tim kerja, manajemen diri dan pengaruh social. Komitmen individual jangka panjang pada organisasi diganjar dengan komitmen jangka panjang organisasi terhadap karyawan.

3. Budaya entrepreneurial, menunjukkan tingkat pengambilan resiko yang tinggi, dinamis dan kreatifitas. Ada komitmen terhadap eksperimentasi, inovasi. Budaya ini tidak hanya cepat bereaksi terhadap perubahan lingkungan, tetapi menciptakan perubahan.

4. Budaya Pasar. Nilai yang akan dicapai terukur, dan karyawan dituntut untuk mencapai sasaran, terutama yang berbasis financial dan pasar.

\section{G. Budaya Organisasi dalam Islam}

Di dalam Islam Budaya merupakan norma, aturan atau nilai-nilai yang harus di patuhi dan dilaksanakan oleh organisasi, selama norma dan aturan tersebut tidak bertentangan dengan ajaran Islam. Pengorganisasian atau organizing secara alamiah merupakan fase kedua (setelah planning) Disamping secara faktual, dalam tataran syariah dari setiap sistem organisasi besar atau sekecil apapun. Dikatakan secara alamiah sebab fakta organizing tersebut secara logical ataupun factual berlaku dimanapun dan kapanpun walaupun dalam bentuk sederhana. ${ }^{16}$

\section{Prinsip Pengorganisasian}

a. Perumusan Tujuan. Organisasi harus menetapkan tujuan yang hendak dicapai yang bersifat fokus, spesifik, terukur, target waktu, memiliki nilai manfaat di sisi Allah Swt. Dalam sebuah kitab Sur'atul Badihah dikatakan bahwa ciri seseorang yang berfikir serius (fikrun jiddiyyah) adalah ditetapkanya tujuan yang kongrit dan tergambar pasti (tashwirul maadah)

b. Kesatuan Arah. Organisasi harus memiliki konsistensi dan komitmen sejak dari pimpinan hingga anggota/bawahan. Pimpinan berkewa-

\footnotetext{
${ }^{16}$ Ndraha, Taliziduhu, Budaya Organisasi, Jakarta: Rineka Cipta, 2003 h. 76
} 
jiban mengurus, mengarahkan, melindungi, dsb. Sementara anggota/ bawahan wajib mendengarkan dan mentaatinya. Hal ini sebagaimana kepemimpinan Rasulullah Saw dan para Khulafaurrasyidin. Rasulullah SAW bersabda: Sesungguhnya pimpinan adalah laksana perisai, tempat orang-orang berperang di belakangnya dan berlindung kepadanya (HR. Muslim).

c. Pembagian Kerja: Organisasi dapat berjalan jika terdapat kejelasan dalam struktur organisasinya dan job deskripsinya. Prinsip ini sudah ada sejak zaman para Nabi terdahulu termasuk Rasulullah Muhammad SAW.

d. Pendelegasian Wewenang dan Tanggung Jawab: Dalam konsepsi Islam terdapat pemikiran yang sangat cerdas, ketika seseorang diangkat menjadi pemimpin maka pada hukum asalnya (ashluhu) dia bertanggung jawab secara keseluruhan terhadap uraian pekerjaan yang telah diamanahkanya, sejak dari hulu hingga hilir, termasuk menetapkan kebijakan hingga peran office boy. Dalam konteks ini terdapat hadits yang sanagt populer dimana Rasulullah SAW mendelegasikan wewenang pemerintahanya dengan mengangkat sahabat Muadz Bin Jabal menjadi wali (setingkat gubernur) di kota Yaman.

e. Koordinasi: Oraganisasi dapat berjalan efektif jika terdapat fungsi koordinasi dengan pihak-pihak terkait dalam sistem ataupun dengan pihak di luar sistem. Hal ini sangat wajar, sebab realitas organisasi hampir dipastikan terdapat struktur lini yang memiliki persamaan level. Mereka harus menjadil kerjasama untuk mencapai tujuan.

f. Rentang Manajemen: Organisasi dapat berjalan sukses jika penempatan tanggung jawab terhadap timnya secara terukur. Misalnya, seorang supervisor hanya bertanggung jawab terhadap pekerjaan 10 orang di bawahnya. Prinsip ini sangat logis sebab manusia memiliki keterbatasan kompetensinya.

g. Tingkat Pengawasan: Organisasi dapat efektif jika terdapat mekanisme controling atau pengawasan yang disusun dan dijalankan secara konsisten. Banyak pekerjaan menjadi gagal jika monitoring lemah. Dalam pandangan Islam, pimpinan memiliki wewenang penuh terhadap fungsi monitoring dengan berbagai metode dan tekniknya. Pada era kekhilafahan Islam, kepala negara acapkali melakukan sidak ke lapangan untuk memastikan efektifitas pendelegasianya. Hal ini berpijak pada hadits shohih yang mengatakan bahwa "Setiap kamu adalah pemimpin dan kelak akan dimintai pertanggungan jawab atas kepemimpinanya".

\section{Karakteristik Budaya Organisasi Islam}

a. Mengajak manusia mengesakan Allah dan memberantas syirik, kekafiran dan Kemunafikan. (QS. An-Nahl [16]: 36).

b. Memberantas kemungkaran terutama semua bentuk keyakinan dan perbuatan syirik. (QS. Al-Hajj [22]: 41)

c. Merealisasikan pernyataan bahwa Muhammad sebagai Rasulullah dalam kehidupan kesehariannya di antaranya menjalankan syari'at Islam yang dibawa oleh Rasulullah SAW. (QS. An Nisaa'[4]: 65).

d. Tidak mau menggunakan hukumhukum selain syari'at Islam sebagai tatanan yang mengatur kehidupan umat manusia di dunia ini. Bila ternyata menolak penerapan syari'at Islam sebagai hukum untuk mengatur tatanan kehidupan di dunia ini, maka organisasi semacam ini jelas bukan 
organisasi Islam. (QS. Al Maidah [5]: 50).

e. Melakukan kontrol terhadap para anggotanya, sehingga tidak sampai terjadi pelanggaran-pelanggaran syari'at di dalam organisasinya dan memberikan nasehat kepada semua anggotanya, pimpinan maupun anak buah. Tersebut dalam hadits dari Abu Ruqayyah Tamim bin Aus Ad Dari, bahwa Nabi SAW. bersabda: "Islam itu (berisikan) nasehat. Kami bertanya: 'Nasehat bagi siapa?'Nabi menjawab: 'Nasehat (untuk mentaati) Allah, kitab-Nya, Rasul-Nya dan nasehat untuk menyadarkan para pemimpin umat Islam dan seluruh kaum muslim." (HR. Muslim)

f. Melakukan kontrol kepada penguasa secara tertutup bukan dengan cara kekerasan atau kritik secara terbuka sehingga menimbulkan permusuhan antara penguasa dengan rakyat. Tersebut dalam hadits bahwa 'Iyad bin Ghanam berkata kepada Hisyam bin Hakim. Tidakkah engkau mendengar Rasulullah SAW. bersabda: 'Barang siapa yang ingin menasehati seorang penguasa (muslim), maka jangan ia lakukan secara terbuka, tetapi hendaklah ia memegang tangannya lalu mengajaknya menyendiri. Jika nasehatnya diterima, maka hal itu baik baginya. Tetapi jika si penguasa menolak maka ia telah melaksanakan kewajiban kepadanya. (HR. Ibnu Abi 'Ashim)

g. Segenap usahanya ditujukan untuk membangun kejayaan dan persatuan umat Islam, bukan untuk kejayaan golongan atau bangsanya sendiri atau kepentingan nasional. Tersebut dalam Hadits dari Abu Hurairah, Rasulullah SAW. bersabda: "Barangsiapa berjuang di bawah bendera fanatisme golongan atau kebangsaan atau ia marah karena membela golongannya atau kebangsaannya, lalu ia terbunuh, maka matinya adalah mati jahiliyah."'(HR. Nasa'i)

h. Membela kepentingan orang mukmin yang dizhalimi oleh orang-orang kafir Allah berfirman pada QS.An Nisaa' [4]:75.

i. Islam dinyatakan dengan jelas sebagai dasar organisasinya dan tujuannya menegakkan syari'at Islam dalam tatanan kehidupan manusia di dunia ini. (QS. Ali 'Imran [3]:19 dan 85).

\section{Pendelegasian Wewenang dan Tanggung Jawab}

Organisasi dapat mencapai target dan sasaran jika berjalanya fungsi pendelegasian wewenang. Dalam konsepsi Islam terdapat pemikiran yang sangat cerdas, dimana ketika seseorang diangkat menjadi pemimpin maka pada hukum asalnya (ashluhu) dia bertanggung jawab secara keseluruhan terhadap uraian pekerjaan yang telah diamanhkanya, sejak dari hulu hingga hilir, termasuk menetapkan kebijakan hingga peran office boy. ${ }^{17}$

Hanya persoalanya, jika seorang pemimpin tersebut tidak mampu menjalankan amanahnya yang demikian besar, maka ia memiliki wewenang untuk mendelegasikan kepada seseorang melaksanakan fungsi suatu pekerjaan hingga tuntas. Dalam konteks ini terdapat hadits yang sanagt populer dimana Rasulullah Saw mendelegasikan wewenang pemerintahanya dengan mengangkat sahabat Muadz Bin Jabal menjadi wali (setingkat gubernur) di kota Yaman. Fakta tersebut dapat dijadikan istinbath hukum bagaimana sistem manajemen dilakukan terutama dalam hal

\footnotetext{
${ }^{17}$ Hasibuan, Malayu S.P., Organisasi dan Motivasi; Dasar Peningkatan Produktivitas, Jakarta: Bumi Aksara, 2007, cet. ke-5 h. 85
} 
pendelegasian wewenang dan tanggung jawab seorang pemimpin.

a. Koordinasi: Oraganisasi dapat berjalan efektif jika terdapat fungsi koordinasi dengan pihak-pihak terkait dalam sistem ataupun dengan pihak di luar sistem. Hal ini sangat wajar, sebab realitas organisasi hampir dipastikan terdapat struktur lini yang memiliki persamaan level. Mereka harus menjadil kerjasama untuk mencapai tujuan. $^{18}$

b. Rentang Manajemen: Organisasi dapat berjalan sukses jika penempatan tanggung jawab terhadap timnya secara terukur. Misalnya, seorang supervisor hanya bertanggung jawab terhadap pekerjaan 10 orang di bawahnya. Prinsip ini sangat logis sebab manusia memiliki keterbatasan kompetensinya.

c. Tingkat Pengawasan: Organisasi dapat efektif jika terdapat mekanisme controling atau pengawasan yang disusun dan dijalankan secara konsisten.

d. Struktur dan Bentuk Organisasi: Islam mengajarkan adanya kepastian struktur organisasi QS. az-Zukhruf [43]: 32 dan dalam hadis Rasulullah SAW Ketika ditanya seseorang tentang bagaimana cara mengkawinkan kurma, beliau hanya menjawab: Antum a'lamu bi umuriddunyakum (kalian lebih mengetahui dengan urusan duniamu).

e. Musyawarah dalam Segala Hal: Dalam mengambil suatu keputusan hendaknya sebuah organisasi melakukan musyawarah terlebih dahulu untuk mencapai mufakat dan tujuan bersama, (QS. As-Syuurah [42]: 38) "Sedang urusan mereka (diputuskan) dengan Musyawarah antara mereka."

${ }^{18}$ Rivai, Veithzal, Kepemimpinan dan Perilaku Organisasi, Jakarta: Rajawali Pers, 2003 h.43

\section{H. Mempertahankan Budaya}

Para pendiri organisasi secara tradisional memiliki pengaruh yang dalam membentuk budaya awal. Mereka memiliki visi bagaimana wujud organisasi tersebut. Mereka tidak dibatasi oleh kebiasaankebiasaan dalam mengerjakan sesuatu atau ideologi-ideologi sebelumnya. Pemberian karakter terhadap organisasi-organisasi baru dengan ruang lingkup yang masih kecil, mempermudah para pendiri dalam menerapkan visinya pada keseluruhan anggota organisasi. Dikarenakan para pendiri tersebut memiliki ide yang masih asli, mereka juga biasanya memiliki bias tentang cara bagaimana ide-ide tersebut bisa terpenuhi. Budaya organisasi dihasilkan dari interaksi antara bias dan asumsi para pendiri dengan apa yang dipelajari selanjutnya oleh anggota awal organisasi dari pengalaman mereka sendiri.

Bila suatu budaya sudah berlaku dalam suatu organiasi, praktik-praktik dalam organisasi berfungsi untuk menjaga budaya dengan cara mengekspos karyawan agar memiliki pengalaman yang serupa. ${ }^{19}$ Untyk dapat menjaga budaya tersebut agar tetap hidup, ada tiga kekuatan yang memainkan peran penting dalam mempertahankannya. Ketiga kekuatan itu adalah:

1. Praktek-praktek seleksi. Tujuan yang jelas dari proses seleksi adalah untuk mengidentifikasi dan mempekerjakan individu-individu yang memiliki wawasan, keterampilan, dan kemampuan dalam melakukan pekerjaan untuk keberhasilan pekerjaan. Tetapi biasanya, akan terdapat lebih dari seorang kandidat yang dapat memenuhi persyaratan dari pekerjaan yang ditawarkan. Keputusan

${ }^{19}$ Robbins, P. Stephen (2005). Organizational Behavior; Elevent Edition. Pearson Education.Inc., Upper Saddle, River. New Jersey. h. 493 
akhir mengenai siapa yang akan dipekerjakan sangat dipengaruhi oleh penilaian pembuat keputusan, yaitu seberapa bagus kandidat-kandidat tersebut memiliki kesesuaian dengan organisasi.

2. Tindakan-tindakan manajemen (manajemen puncak). Tindakan manajemen puncak juga memiliki dampak utama terhadap budaya organisasi. Para eksekutif membentuk norma-norma penyaring yang menyeluruh didalam organisasi melalui apa yang mereka katakan dan mereka lakukan. Apakah pengambilan resiko lebih mereka kehendaki, seberapa besar keleluasaan yang harus diberikan manajer terhadap bawahannya, seragam apa yang dipakai, tindakan apa yang harus dilakukan untuk kenaikan gaji, promosi, dan penghargaan-penghargaan lainnya, dan lain sebagainya.

3. Metode sosialisasi; Karyawankaryawan baru memiliki kecendrungan untuk mengganggu kepercayaan dan kebiasaan yang sudah berlaku. Dengan demikian, organisasi perlu membaantu karyawan baru tersebut dalam beradaptasi dengan budaya mereka. proses adaptasi ini disebut sosialisasi. Tahap sosialisasi yang paling penting adalah ketika karyawan baru masuk ke dalam organisasi. Tahap ini merupakan saat-saat dimana organisasi berusaha untuk membentuk karakter orang luar yang baru masuk mejadi karyawan dengan cara "penempatan diri yang baik".

\section{Penutup}

Budaya organisasi dapat diartikan sebagai nilai, norma, aturan, falsafah, dan kepercayaan yang diyakini oleh sebuah organisasi yang tercermin dala pola pikir dan perilaku para anggota organisasi. Budaya organisasi memiliki kegunaan sebagai pembeda dengan organisasi lainnya, sebagai identitas anggota sebuah organisasi, sebagai komitmen anggota di atas kepentingan bersama., sebagai perekat sosial dengan menyediakan standar yang anggota harus lakukan dan katakana, dan berguna pula sebagai mekanisme kontrol yang membentuk perilaku anggota. Mengingat budaya organisasi merupakan nilai, kepercayaan bersama para anggota organisasi, tentu budaya ini hendaknya senantiasa terus dibangun dan dibina dalam organisasi. Hal ini terkait dengan berbagai macam latar belakang anggota organisasi. Budaya organisasi yang dikelola akan memberikan dampak positif pada kinerja institusi secara umum, karena budaya organisasi tersebut akan mengarahkan perilaku para anggota organisasi. Dalam lembaga pendidikan Islam, budaya organisasi terus dibangun dan dibina dengan tujuan untuk mengejawantahkan ajaran dan nilai-nilai Islam yang pada akhirnya akan menjadi budaya Islami.

\section{DAFTAR PUSTAKA}

Haryo S Martodirjdo, Pemahaman Lintas Budaya, Jakarta: PT. Raja Grafindo, 2004

Hasibuan, Malayu S.P., Organisasi dan Motivasi; Dasar Peningkatan Produktivitas, Jakarta: Bumi Aksara, 2007, cet. ke-5

Hikmat, "Manajemaen Pendidikan", Bandung: Pustaka Setia, 2011

Ndraha, Taliziduhu, Budaya Organisasi, Jakarta: Rineka Cipta, 2003

Joko Tri prasetya, et. all., Ilmu Budaya Dasar, Jakarta: MKDU, 2004

Mudji Sutrisno, Teori-Teori Kebudayaan, Jakarta: YKPN, 2003)

Ndraha, Taliziduhu, Budaya Organisasi, Jakarta: Rineka Cipta, 2003

O'Reilly; Chatman, J; Caldwell, D. F. "People and Organizational Culture: 
A Profile Comparison Approach to Assessing Person-Organization Fit," Academy of Management Journal

Robbins, Stephen P. Judge, Timothy A. Perilaku Organisasi Buku 2, Jakarta: Salemba Empat. 2008.

Robbins, P. Stephen. Organizational Behavior; Elevent Edition. Pearson Education.Inc., Upper Saddle, River. New Jersey. 2005

Schein, E. H. Organizational Culture and Leadership, San Fransisco: JosseyBass, 1985.

Soetopo, Hendyat. Perilaku Organisasi; Teori dan Praktek di Bidang Pendidikan. Bandung. Remaja Rosdakarya. 2010
Soetopo, Hendyat .Perilaku Organisasi; Teori dan Praktek di Bidang Pendidikan. Bandung. Remaja Rosdakarya, 2010

Rivai, Veithzal, Kepemimpinan dan Perilaku Organisasi, Jakarta: Rajawali Pers, 2003

Tim Dosen, AP. UPI. Manajemen Pendidikan. Bandung. Alfabeta, 2009

Wayne K.Hoy dan Cecil G.Miskel, Administrasi dan Pendidikan (Teori, Riset, dan Praktik) diterjemahkan dari "Educational Administrational" Pustaka Pelajar Yogyakarta, 2013 
Budaya Organisasi dalam Pendidikan Islam

Rausyan Fikr. Vol. 16 No. 1 Maret 2020. ISSN. 1979-0074 e-ISSN. 9772580594187 | 62 